\title{
Are remittances an instrument of stabilization and funding in the euro area?
}

\section{Correia \& P. Martins}

To cite this article: L. Correia \& P. Martins (2016) Are remittances an instrument of stabilization and funding in the euro area?, Applied Economics Letters, 23:16, 1177-1181, DOI: 10.1080/13504851.2016.1142647

To link to this article: https://doi.org/10.1080/13504851.2016.1142647

\section{Published online: 08 Feb 2016.}

Submit your article to this journal $匚$

Џ Article views: 140

Q View related articles $\widetilde{ }$

View Crossmark data $₫$

Citing articles: 2 View citing articles ๘ 


\title{
Are remittances an instrument of stabilization and funding in the euro area?
}

\author{
L. Correia (1) and P. Martins (1) \\ Centre for Transdisciplinary Development Studies (CETRAD), Department of Economics, Sociology and Management (DESG), University of \\ Trás-os-Montes and Alto Douro (UTAD), Vila Real, Portugal
}

ABSTRACT

In this study, we explore the specific question of the counter cyclicality of remittances in the euro area, namely, if they could be used to stabilize the business cycle and as an additional source of external financing. This research uses data for 13 euro area countries in the period 2004-2013. For whole of the sample, our two hypotheses concerning stabilization and external financing are rejected, but Lithuania and Greece are outliers. Remittances seem to have had a macroeconomic stabilizing effect on Lithuania and to have mitigated in part the liquidity problems that Greece has faced since the sovereign debt crisis.

\section{KEYWORDS}

Remittances; business cycles; procyclical; countercyclical; euro area

JEL CLASSIFICATION

E32; F24

\section{Introduction}

In the last decade, a growing number of papers have focused on the important role of remittances, their determinants and effects. Most of the existing literature has concentrated predominantly on microeconomic aspects, but more recently several studies have focused on the macroeconomic impact of remittances on economic growth, mainly for developing countries. However, this literature has produced mixed and sometimes controversial results, depending substantially on the sample of countries and their specific characteristics. Several studies have found a positive impact (Ziesemer 2012; Giuliano and Ruiz-Arranz 2009; Acosta et al. 2008), whereas others conclude there are negative (Le 2009; Chami, Fullenkamp, and Jahjah 2005) or nonsignificant effects (Senbeta 2013).

Another line of research concerns the specific question of how remittances react to business cycles in the receiving country. The empirical results remain inconclusive. Some studies present evidence for countercyclical remittances (Vargas-Silva 2008; Frankel 2011), whereas others conclude there are procyclical remittances (Lueth and Ruiz-Arranz 2006; Giuliano and Ruiz-Arranz 2009).

The discussion concerning the cyclicality of remittances has a theoretical foundation in the literature that explores the motives for migrants remitting. There are several potential reasons for remitting, but altruistic purposes and motives of self-interest are the most important (Knerr and Hamann 2006). The hypothesis of countercyclical behaviour is based on evidence suggesting that altruistic purposes prevail, i.e. migrants remit more when the economic conditions in their countries of origin deteriorate to compensate their families for the drop in income levels. In this case, the receiving countries could potentially use the remittances to stabilize the business cycle, smoothing consumption and investment temporarily (World Bank 2006). In contrast, remittances sent for motives of self-interest may decrease when there are economic downturns in the home country because there is a worsening of investment opportunities and a negative impact on inheritance from the household's assets. In this case, remittances tend to be procyclical and cannot be used to offset negative cyclical fluctuations in the output of the home country.

The relationship between remittances and the business cycle of the host country is also relevant. If remittances are countercyclical with respect to the output in the receiving country and procyclical with respect to the output of the sender country, they may have a significant impact on smoothing macroeconomic fluctuations in recipient countries (smoothing hypothesis), and they could assume the role that it is assigned to capital flows but that is often not played out in practice. 
This article concerns this smoothing hypothesis. The main purpose is to investigate empirically this hypothesis in the context of the euro area, an aspect that, as far as we know, has not yet been examined. The study is motivated by the ambivalent findings in the existing literature and relates to the statement of Frankel (2011) that if remittances are countercyclical, they should join the list of optimum currency area (OCA) criteria. We use a panel model for 13 euro area countries over the period 2004-2013.

The rest of the article is organized as follows. Section II presents the data and empirical specification. Section III discusses the empirical results. Section IV concludes the study.

\section{Data and empirical specification}

Our sample includes Austria (AT), Belgium (BE), Cyprus (CY), Germany (DE), Greece (EL), Finland (FI), Italy (IT), Lithuania (LT), Luxembourg (LU), the Netherlands (NL), Portugal (PT), Slovenia (SI) and Slovakia (SK). As we do not use bilateral remittances, we identified the main European Union (EU) host country and the main host country (Table A in the Appendix) for each country, taking into account the respective inflows of European and total remittances, respectively. ${ }^{1}$ We define two specific research hypotheses as follows:

H1 - European remittances are countercyclical regardless of the cyclical position of the economy of the main EU host country;

H2 - European remittances alleviate potential problems of funding or liquidity.

To test these assumptions, we use the following baseline model:

$$
\begin{aligned}
\text { EURe } m_{i, t}= & \beta_{1}\left(G D P_{i, t} * \text { positive GDP host } \text { hitt }_{i, t}\right) \\
& +\beta_{2}\left(G D P_{i, t} * \text { negative GDP host }{ }_{i, t}\right) \\
& +\beta_{3} \text { yield difference } i, t+u_{i, t}
\end{aligned}
$$

The explained variable is the cycle of European remittances of home country $i$ in the year $t$, i.e. the cycle of real remittances received from EU countries. The three explanatory variables are the GDP cycle of country $i$ if the GDP cycle of the main EU host country is positive, the GDP cycle of country $i$ if the GDP cycle of the main EU host country is negative and the difference between bond yields. ${ }^{2}$

The first two interaction variables are used to test the counter cyclicality hypothesis (H1). We investigate the cyclical nature of remittances with respect to the GDP of the home country when the GDP of the main EU host country is above-trend or belowtrend, respectively. These variables seem more appropriate than the difference in cyclical position between the host country and the home country, used by Frankel (2011), for three reasons: (1) our data are not bilateral remittances; (2) there are high correlation coefficients between the respective GDP cycles $^{3}$; (3) the cyclical position of the economy of the main EU host country may influence the disposable income of migrants and their expectations of permanence in that country.

The difference between bond yields is a variable related to $\mathrm{H} 2$. When this variable is positive, it is more expensive for the government of the home country to borrow than for the government of the main EU host country. We intend to investigate if the European remittances are an additional source of external financing, alleviating the potential funding problems of governments, banks and the nonfinancial sector that were of particular importance in the period of financial and sovereign debt crisis in some euro area countries. This hypothesis is not rejected if the estimated coefficient is significant and the sign is positive.

\section{Empirical results}

We suspected the existence of a heterogeneous behaviour of remittance cycles between countries (Fig. 1). Thus, to identify possible outliers, we excluded one country at a time from the sample. As expected, the estimated coefficients change qualitatively in the case

\footnotetext{
${ }^{1}$ The choice of countries and the period of analysis were constrained by the availability of data regarding remittances.

${ }^{2}$ The description and sources of these variables are presented in Table B in the Appendix.

${ }^{3}$ For the whole sample, the correlation coefficient is 0.70 and only the pairwise correlation coefficients for Cyprus and Greece are not significant at the $5 \%$ level.
} 

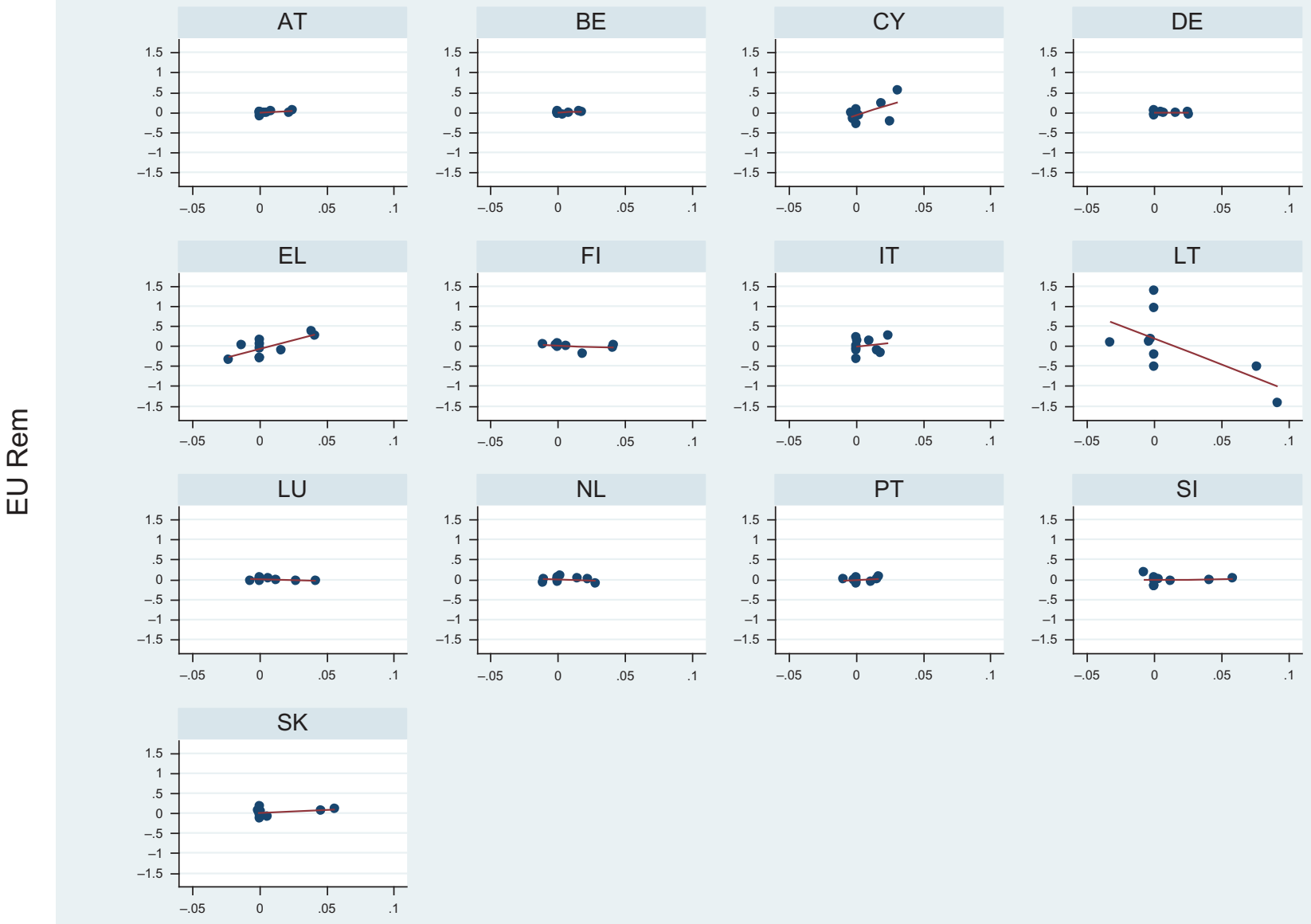

GDP*positiveGDPhost

Figure 1. Cycle of EU remittances and GDP cycle of home countries.

of Lithuania and Greece. Thus, we included interaction terms between the three explanatory variables of the baseline model and the dummy variables for these two countries. ${ }^{4}$

Based on the results of the Hausman and BreushPagan LM tests ( $p$-values of 0.955 and 1.000, respectively), pooled estimation seems more appropriate than fixed effects (FE) and random effects (RE) models. The respective estimated coefficients are reported in column A of Table 1.

The three explanatory variables of the baseline model are all nonsignificant. In the case of Lithuania, there is a strong countercyclical relation between GDP and remittances, regardless of the economic situation in the main EU host country (UK). The estimated coefficient is higher in absolute value when the GDP in the main EU host country is below-trend than when it is above-trend, probably because in bad times the migrants have more fear of losing their jobs and having to return to the country of origin.

For Greece, the remittances present a procyclical behaviour when the GDP cycle of the main EU host country (DE) is positive. When the economic conditions are good in the host country, migrants send remittances to Greece mainly to invest. In the years before the crisis (2004-2008), Greece's remittance cycles diminished when the yield on Greece government bonds was higher than the yield on German bonds. However, after the global financial crisis (2009-2013), as the yield spread between the two governments bonds increased, the remittances also increased. This change may have moderated the liquidity problem that Greece has faced since 2009. 
Table 1. Panel data results.

\begin{tabular}{|c|c|c|c|}
\hline Variables & $\begin{array}{c}\text { Pooled OLS } \\
\text { A }\end{array}$ & $\begin{array}{l}\text { Pooled OLS } \\
\text { B }\end{array}$ & $\begin{array}{l}\text { Panel FE } \\
\text { C }\end{array}$ \\
\hline$G D P_{i, t} *$ positive GDP host $t_{i, t}$ & $\begin{array}{c}1.376 \\
(0.868)\end{array}$ & $\begin{array}{r}-0.190 \\
(0.190)\end{array}$ & $\begin{array}{l}-2.670 \\
(1.804)\end{array}$ \\
\hline$G D P_{i, t} *$ negative GDP host $t_{i, t}$ & $\begin{array}{c}0.239 \\
(1.053)\end{array}$ & $\begin{array}{c}-0.059 \\
(0.223)\end{array}$ & $\begin{array}{c}-3.197 \\
(1.932)\end{array}$ \\
\hline yield difference $_{i, t}$ & $\begin{array}{l}0.001 \\
(0.006)\end{array}$ & $\begin{array}{l}0.014 \\
(0.009)\end{array}$ & $\begin{array}{c}0.012 \\
(0.008)\end{array}$ \\
\hline $\begin{array}{l}G D P_{i, t} * \text { positive GDP host } \\
\text { LT }\end{array}$ & $\begin{array}{c}-11.082^{* * *} \\
(1.503)\end{array}$ & $\begin{array}{l}2.053^{* * *} \\
(0.246)\end{array}$ & $\begin{array}{l}-5.792^{* * *} \\
(1.323)\end{array}$ \\
\hline $\begin{array}{l}\operatorname{GDP}_{i, t} * \text { negative GDP host } \\
\text { LT }\end{array}$ & $\begin{array}{l}-20.425^{* * *} \\
(3.002)\end{array}$ & $\begin{array}{l}2.266^{* * *} \\
(0.760)\end{array}$ & $\begin{array}{l}-12.786^{* * *} \\
(2.054)\end{array}$ \\
\hline $\begin{array}{l}G D P_{i, t} * \text { positive GDP host }{ }_{i, t}{ }^{*} \\
\text { EL }\end{array}$ & $\begin{array}{l}16.373^{* * *} \\
(3.451)\end{array}$ & $\begin{array}{l}-4.960^{* * *} \\
(0.875)\end{array}$ & $\begin{array}{l}6.383^{* * *} \\
(1.109)\end{array}$ \\
\hline $\begin{array}{l}G D P_{i, t} * \text { negative GDP host } t_{i, t} * \\
\text { EL }\end{array}$ & $\begin{array}{l}2.186 \\
(2.325)\end{array}$ & $\begin{array}{c}-0.588 \\
(0.564)\end{array}$ & $\begin{array}{l}11.408^{* * *} \\
(2.775)\end{array}$ \\
\hline $\begin{array}{l}G D P_{i, t} * \text { positive GDP host }{ }_{i, t}{ }^{*} \\
C Y\end{array}$ & & $\begin{array}{l}-1.293^{* *} \\
(0.636)\end{array}$ & \\
\hline $\begin{array}{l}G D P_{i, t} * \text { negative GDP host } t_{i, t} * \\
\quad \mathrm{YY}\end{array}$ & & $\begin{array}{l}1.516^{* *} \\
(0.695)\end{array}$ & \\
\hline yield difference $e_{i, t}{ }^{*} \mathrm{LT}$ & $\begin{array}{c}-0.279 \\
(0.178)\end{array}$ & $\begin{array}{l}-0.570^{* * *} \\
(0.186)\end{array}$ & $\begin{array}{l}-0.498^{* * *} \\
(0.033)\end{array}$ \\
\hline $\begin{array}{l}\text { yield difference }{ }_{i, t} * \mathrm{LT} * \text { crisis } \\
\text { years }\end{array}$ & $\begin{array}{c}0.266 \\
(0.179)\end{array}$ & $\begin{array}{l}0.603^{* * *} \\
(0.190)\end{array}$ & $\begin{array}{l}0.530^{* * *} \\
(0.033)\end{array}$ \\
\hline yield difference ${ }_{i, t}{ }^{*} \mathrm{EL}$ & $\begin{array}{l}-0.744^{* * *} \\
(0.243)\end{array}$ & $\begin{array}{l}-0.857^{* * *} \\
(0.196)\end{array}$ & $\begin{array}{c}0.039 \\
(0.034)\end{array}$ \\
\hline $\begin{array}{l}\text { yield difference } i, t{ }^{*} \text { EL }{ }^{*} \text { crisis } \\
\text { years }\end{array}$ & $\begin{array}{l}0.751^{* * *} \\
(0.246)\end{array}$ & $\begin{array}{l}0.866^{* * *} \\
(0.199)\end{array}$ & $\begin{array}{r}-0.048 \\
(0.031)\end{array}$ \\
\hline Constant & $\begin{array}{l}-0.016 \\
(0.012)\end{array}$ & $\begin{array}{c}-0.032 \\
(0.021)\end{array}$ & $\begin{array}{r}-0.052^{*} \\
(0.024)\end{array}$ \\
\hline Time effects & No & Yes & Yes \\
\hline $\begin{array}{l}\text { Time effects significance, } \\
p \text {-values }\end{array}$ & 0.1858 & 0.052 & 0.031 \\
\hline Country effects & No & No & Yes \\
\hline $\begin{array}{l}\text { Country effects significance, } \\
p \text {-values }\end{array}$ & 0.5235 & 0.313 & 0.008 \\
\hline $\begin{array}{l}\text { Observations } \\
R^{2}\end{array}$ & $\begin{array}{r}129 \\
0.78\end{array}$ & $\begin{array}{l}129 \\
0.76\end{array}$ & $\begin{array}{c}129 \\
0.87\end{array}$ \\
\hline
\end{tabular}

Note: Robust SE are given in parentheses.

$* * * * *, *$ Denote significance at the $1 \%, 5 \%$ and $10 \%$ levels, respectively.

\section{Robustness checks}

To check the robustness of our results, we used two different data sets. In the first, the cyclical position of the economy is represented by the unemployment rate instead of GDP (Table 1, column B). In the second data set, the explained variable is the cycle of total remittances received by the home country (Table 1 , column C). ${ }^{5}$ With regard to total remittances, Eurostat does not report data for Slovakia (included in the main sample), but it reports information for Spain (not included in the main sample). Due to this data constraint and because we leave one country out at time to check the results, the sample was reshaped to preserve the number of observations. The explanatory variables were computed with statistical information for the main host country as in some home countries the respective main host country is not a member state of the EU.

As before, the remittances are countercyclical in Lithuania and this relation is even stronger when the economic conditions in the main host country, the UK, are unfavourable. The results also confirm the procyclical behaviour of Greece's remittances when the unemployment rate of the main EU host country (DE) is below the trend. The Greece's total remittances also present a procyclical behaviour, but they do not depend on the GDP cycle of the US, the main host country of Greece.

When we consider the unemployment rates, Cyprus is also an outlier country. The relationship between European remittances and unemployment rates depends on the economic situation of the main EU host country (UK), being procyclical in good times and countercyclical in bad times.

The interaction terms between the difference between bond yields and the country dummy variables for Lithuania and Greece are all significant when we use the unemployment rate and are only significant in case of Lithuania when the explained variable is total remittances. As before, as the difference between bond yields increases, the remittance cycles shrink, except in the crisis years (2009-2013) when the estimated coefficients are positive although very small.

\section{Conclusions}

For 13 euro area countries in the period 2004-2013, we reject the hypotheses of the counter cyclicality of remittances and of their use as an additional source of external financing, but Lithuania and Greece are outliers.

The European (and total) remittances of Lithuania are countercyclical. This relationship is even stronger when the GDP of the main host country is below-trend than when that country is experiencing good times, probably because the altruism of migrants increases when they fear having to return home. This is an interesting result as this country received positive net remittances in all the periods analysed. The European remittances of Greece are procyclical when the GDP of Germany (the main EU host country) is above-trend and the total remittances are procyclical regardless of the cyclical position of the US economy (the main host

\footnotetext{
${ }^{5}$ As previously, the choice of the most appropriate estimation technique was supported by the results of the Hausman and Breush-Pagan LM tests.
} 
country). Thus, the migrants of Greece remit mainly to invest.

The difference between the bond yields of home and host governments explains the cycle of total remittances of Lithuania and the cycle of European remittances of Greece. During the crisis years, as that difference increased, the remittances received were an additional source of external financing for these countries.

To conclude, remittances seem to have had a macroeconomic stabilizing effect in Lithuania and mitigated in part the liquidity problems that Greece has faced since the sovereign debt crisis.

\section{Disclosure statement}

No potential conflict of interest was reported by the authors.

\section{Funding}

This work was supported by national funds provided by the Portuguese Foundation for Science and Technology (FCT) [project number UID/SOC/04011/2013].

\section{ORCID}

L. Correia (D) http://orcid.org/0000-0002-2762-6965

P. Martins (D) http://orcid.org/0000-0002-4493-963X

\section{References}

Acosta, P., C. Calderón, P. Fajnzylber, and H. Humberto. 2008. "What is the Impact of International Remittances on Poverty and Inequality in Latin America?" World Development 36 (1): 89-114. doi:10.1016/j.worlddev.2007.02.016.

\section{Appendix}

Table A. Home countries and main host countries.

\begin{tabular}{lll}
\hline $\begin{array}{l}\text { Home } \\
\text { country }\end{array}$ & \multicolumn{1}{c}{ Main EU host country } & \multicolumn{1}{c}{ Main host country } \\
\hline AT & DE & DE \\
BE & LU & LU \\
CY & UK & UK (2004-2008) \\
& & RU (2008-2013) \\
DE & DK & CH \\
EL & DE & US \\
FI & SE & CH \\
IT & DE (2004-2006) & DE (2004-2006) \\
& UK (2007-2009) FR (2010- & UK (2007) CH (2008- \\
& 2013) & 2013) \\
LT & UK & UK \\
LU & DE & DE \\
NL & UK & UK \\
PT & FR & FR \\
SI & AT & AT \\
SK & CZ & CZ \\
\hline
\end{tabular}

Note: United Kingdom (UK), Denmark (DK), Sweden (SE), France (FR), Czech Republic (CZ), Russia (RU), Switzerland (CH), United States (US).
Baxter, M., and R. King. 1999. "Measuring Business Cycles: Approximate Band-Pass Filters for Economic Time Series." The Review of Economics and Statistics 81: 575593. doi:10.1162/003465399558454.

Chami, R., C. Fullenkamp, and S. Jahjah. 2005. "Are Immigrant Remittance Flows a Source of Capital for Development?” IMF Staff Papers 52 (1): 55-81.

Frankel, J. 2011. "Are Bilateral Remittances Countercyclical?" Open Economies Review 22: 1-16. doi:10.1007/s11079-0109184-y.

Giuliano, P., and M. Ruiz-Arranz. 2009. "Remittances, Financial Development, and Growth." Journal of Development Economics 90 (1): 144-152. doi:10.1016/j. jdeveco.2008.10.005.

Knerr, B., and V. Hamann. 2006. "The Impact of International Labor Migration on Regional Development: The Example of Zacatecas, Mexico." Kassel University Press, Germany 2: 1-207.

Le, T. 2009. "Trade, Remittances, Institutions, and Economic Growth.” International Economic Journal 23 (3): 391-408. doi:10.1080/10168730903119443.

Lueth, E., and M. Ruiz-Arranz. 2006. "A Gravity Model of Workers' Remittances.” IMF Working Papers No 06/290. $10.5089 / 9781451865509.001$

Senbeta, A. 2013. "Remittances and the Sources of Growth." Applied Economics Letters 20: 572-580. doi:10.1080/ 13504851.2012.718057.

Vargas-Silva, C. 2008. “Are Remittances Manna from Heaven? A Look at the Business Cycle Properties of Remittances." The North American Journal of Economics and Finance 19 (3): 290-303. doi:10.1016/j.najef.2008.03.001.

World Bank. 2006. Global Economic Prospects: Economic Implications of Remittances and Migration. Washington: The World Bank.

Ziesemer, T. H. W. 2012. "Worker Remittances, Migration, Accumulation and Growth in Poor Developing Countries: Survey and Analysis of Direct and Indirect Effects." Economic Modelling 29 (2): 103-118. doi:10.1016/j. econmod.2011.08.013.

Table B. Variables: definition and sources.

\begin{tabular}{|c|c|c|}
\hline Variable & Definition & Source \\
\hline$E U \operatorname{Rem}_{i, t}$ & $\begin{array}{l}\text { Cycle of logarithm of real remittances } \\
\text { of home country } i \text { in the year } t \\
\text { received from EU; remittances are the } \\
\text { credit flow of workers' remittances } \\
\text { and compensation of employees, in } \\
\text { million euro; to convert nominal } \\
\text { remittances into } 2010 \text { constant prices, } \\
\text { the GDP deflator was employed; cycle } \\
\text { obtained by applying the BK filter } \\
\text { (Baxter and King 1999) }\end{array}$ & Eurostat \\
\hline$G D P_{i, t}$ & $\begin{array}{l}\text { Cycle of logarithm of real GDP of } \\
\text { country } i \text { in year } t \text {; GDP expressed at } \\
2010 \text { constant prices, in million euro; } \\
\text { cycle obtained by applying the BK } \\
\text { filter }\end{array}$ & Eurostat \\
\hline yield difference $e_{i, t}$ & $\begin{array}{l}\text { Difference between bond yields' long- } \\
\text { term interest rates (yield on } \\
\text { government bonds with a maturity of } \\
10 \text { years); expressed in percentage } \\
\text { points }\end{array}$ & $\begin{array}{l}\text { European } \\
\text { Central Bank } \\
\text { and OECD }\end{array}$ \\
\hline
\end{tabular}

